\title{
REFLECTIONS ON GOOD GOVERNANCE, DEVELOPMENT AND JUDICIAL REFORM: SOME PERSPECTIVES ON THE PROBLEM OF JUDICIAL CORRUPTION*
}

\author{
Florentino P. Feliciano**
}

\section{PRELIMINARY - GENERAL CONSIDERATIONS}

This brief essay proposes to focus on the problem of corruption in the judicial department of government. Its more specific objective is to address some of the aspects of this problem relating to judges themselves, as distinguished from officials and staff of auxiliary or support offices in the judicial department such as clerks of court or court registrars; court administrators; and sheriffs or enforcement-related officers. These latter types of subordinate officials present different kinds of regulatory or control problems than do judges, problems which do not seem to differ qualitatively from those which relate to officials in the executive department of government.

Two aspects of the problem of judicial corruption will be explored in this essay: the first relates to the context in which corruption among judges takes place; the second is concerned with the strategies or modes of control which are being employed to reduce or mitigate the incidence of judicial corruption. Necessarily, this paper draws from experience in my own country, since this is the only part of the world with which I have sufficient detailed familiarity.

These aspects are sought to be presented in terms sufficiently concrete and operational so as to generate a feel of the 'real world', as it were, in which the judiciary operates in the Philippines. Preliminarily, however, it seems useful to explore some considerations of a fairly general nature which bear upon the subject of judicial corruption and reform and good governance.

The first general submission which may be made is that - whatever else it may be - and it is often referred to as a social and economic and institutional

\footnotetext{
* This essay is based on an address delivered on 11 January 1999 at a Symposium at the East Asian Legal Studies Program, Harvard Law School. The address in turn constituted a revision and enlargement of a paper delivered at a Conference held in Rome, Italy, under the aegis of the International Development Law Institute (IDLI) and the Avvocatura Generale dello Stato, Government of Italy, in April, 1998. An earlier version of the present paper was published in 73 Philippine Law Journal (1999) 429-445. The essay will also be included in the Liber Amicorum for IBRAHIM F.I. SHIHATA.

** Member, Appellate Body, World Trade Organization, Geneva; Senior Associate Justice, Supreme Court of the Philippines (retired).
}

Asian Yearbook of International Law, Volume 7 (Ko Swan Sik et al., eds.

${ }^{\circ}$ Kluwer Law International; printed in the Netherlands), pp. 3-19 
problem - judicial corruption is at bottom a personal and moral problem. From this perspective, a judge's response to a corrupt promise of some sum of money or of higher office or of any of the multitude of things that commonly are objects of human desire, will be affected by, inter alia, the judge's personal conception of his relationship with the rest of the universe. Given the ultimate nature of the problem of judicial corruption, judicial reform must realistically draw upon the well-springs and methods of moral reform and these of course include religious and spiritual and social resources and methods. One lesson that history teaches us is that movements aimed at basic moral and social reform are often accompanied by religious fundamentalism. This was true in the Reformation of the late medieval Christian Church in the $15^{\text {th }}$ century by MARTIN LUTHER and the Counter-Reformation of St. IGNATIUS OF LOYOLA. Recall, in more recent times, the role of fundamentalist Islam in the revolution against and eventual overthrow of the Shah of Iran; of the so-called 'liberation theology' of many Catholic priests in Central and South America during the decades of the 1960s, 1970s and 1980s; and the strategic role of the Catholic Church in the Philippines in the 1986 revolution against the MARCOS regime.

A second general point that may be worth making is that corruption in the judiciary is a reflection of corruption in the civil service of a country. And the latter may be a symptom of corruption in the private sector and in society itself. Significant corruption among judges does not, and cannot, exist autonomously where the rest of the civil service and the civil society are substantially unaffected and in a healthy condition.

My third general consideration is in part a trite one: it is that corruption, public and private, has existed, and does exist, in all forms of human society as we know it from history. ${ }^{1}$ Nevertheless, certain cultural factors in a particular

${ }^{1}$ J.T. NOONAN, Jr., Bribes: The intellectual history of a moral idea (Univ. of California Press, 1984) traces the 4000 year history of the concept of a bribe in the context of the culture or society in which the bribe-giver and the bribe-taker carry out their non-legitimate reciprocity. NOONAN (a judge of the Ninth Circuit US Court of Appeals and Robbins Professor of Law Emeritus, University of California, Berkeley) describes the central concept of a bribe as "an inducement improperly influencing the performance of a public function meant to be gratuitously exercised. The concrete constituent elements ... change with culture. The concept of a bribe contracts or expands with conventions, laws, practices". (p. xi) NOONAN's work remains the standard scholarly examination of the moral philosophy, law and cultural anthropology of various societies' responses to, and efforts to control, corruption, including in particular judicial corruption.

W. M. REISMAN, Folded lies: bribery, crusades and reforms (Free Press, 1979) p.2 and chap.2, refers to bribery as "tendering and accepting a private reward for defection from a manifest duty". He distinguishes between a 'myth system' and an 'operational code': "an observer may distinguish in any social process, a myth system that clearly expresses all the rules and prohibitions (the 'rights' and 'wrong' of behaviour expressed without nuances and shadings), and an operational code that tells 'operators' when, by whom, and how certain 'wrong' things may be done. An operator is someone who knows the code in his own social setting certain lawyers, some police officers, some business men, an agent, a kid at school". (op.cit. at 1). The myth systems of all human societies stigmatise varying forms of bribery; the operational codes of differing segments of a society frequently recognise that bribery continues to be prac- 
society may bear significantly upon the incidence, growth and amenability to legal and social controls of corruption in general, and judicial corruption in particular. This is clearly a task for social anthropologists, but certain fairly common features in Philippine culture need examination in this regard. For instance, (a) deference to authority is clearly a desirable thing insofar as generating habits of law-observance is concerned; but it also makes difficult open complaints against and reporting or denouncing dishonest or incompetent public officials. (b) 'Pakikisama' - one aspect of which relates to submission to demands for group harmony and reluctance to 'upset the official applecart,' - is important in a society like ours which prizes consensus-building; however, such reluctance frequently renders problematical the discovery and investigation of official wrongdoing. (c) The concept of gratitude as constitutive of a personal social debt or obligation seems of central relevance. Gratitude for what? Among other things, for securing or assistance in securing a judicial appointment or promotion. Most generally put, the relevant point appears to be that the agenda of judicial

reform must include, among other things, the gradual modification of the systems of identifications and loyalties prevailing in our society. Effective identification with national ideals and institutions will need to be cultivated; loyalties to family clan or linguistic tribe or other sub-grouping will need to be restructured and modernized.

Another general submission which may be essayed is that judicial corruption is particularly deleterious in its consequences for the institutions of government and the body politic in general. Corruption of any public officer or employee is bad enough; corruption of a judicial officer is infinitely worse. The judicial process is often described as a system for delivery of justice; it is also sometimes described as a system and process for resolution of disputes. In responsible and representative governments, both the delivery of justice and the resolution of disputes are to be carried out on the basis of and in accordance with law. From this perspective, one effect of judicial corruption may be seen to be the substitution of the private exclusive interest of one of the parties to the dispute, and of the judge, instead of the inclusive interest of the general community, as expressed in law, as the effective determinant of decision. In this very basic sense, judicial corruption subverts the role of law as the authoritative instrument of peaceful and legitimate change in society.

Insofar as impact upon the legal system is concerned, it may be observed that corrupt judgments may be rendered with or without distortion of the written norm. There is no necessary distortion of the relevant norm if that norm itself contemplates the exercise of judicial discretion within certain limits and the corrupt decision is rendered arguably within the limits of that discretion.

ticed, under differing names and in varying circumstances, notwithstanding the prohibitory norms of the myth system. He describes his book as "an attempt at exploration into the interrelations of the myth system and operational code as they pertain to bribery. It is a study of the processes and techniques of social stabilization rather than of social change" (op.cit. at 6). 
The result, in other words, may be reached without a clear and palpable violation of the applicable norm. The ensuing result may even be plausibly regarded as the correct or a reasonable outcome normatively speaking; in such situation, the detection and proof of accompanying judicial corruption becomes more difficult. $^{2}$ The judge, however, who acts from a corrupt motive and receives extra-judicial consideration, nevertheless commits a separate violation of the criminal law. ${ }^{3}$ Where the terms of the applicable legal norm do not allow the exercise of discretion by the judge, or where the result is otherwise evidently inconsistent with the requirements of the norm, the corrupt decision necessarily

\footnotetext{
${ }^{2}$ Prof. G. GUNTHER in his authoritative biography of Judge LEARNED HAND (Learned Hand: the man and the judge (Harvard Univ. Press, 1995), ch.XII) provides detailed, fascinating illustration in respect of Chief Judge MARTIN MANTON who was forced to resign from the Second Circuit Court of Appeals in February 7, 1939. The resignation came after then N.Y. County District Attorney THOMAS E. DEWEY forwarded to the Chairman of the House of Representatives Judiciary Committee whose tasks include consideration of possible impeachment, detailed charges concerning receipt by Chief Judge MANTON, in six incidents, of more than US $\$ 400,000$ from parties involved in litigation before the Second Circuit.

Judge LEARNED HAND himself had sat in two cases in which MANTON had accepted bribes. In the first case, General Motors Corp. v. Preferred Electric \& Wire_Corp. 79 F.2d 621 (2d. Cir. 1935), the Second Circuit (MANTON, LEARNED HAND and SWAN, JJ.) unanimously invalidated the General Motors patent on which suit was brought. The pre-conference memoranda showed that all three judges agreed on the result from the outset and that nothing in MANTON's memorandum "could clearly provoke suspicions of corruption" and that MANTON's analysis of the legal issues closely resembled those of HAND and SWAN. (GUNTHER, op.cit. supra at 506507) The Second Circuit, on rehearing granted after MANTON had resigned, been charged and convicted, upon a fresh review of the old record and with full knowledge of MANTON's bribery, once again found the patents invalid; 109 F.2d 615 (2d Cir. 1940).
}

The second case was much more complex: Art Metal Works v. Abraham \&_Straus, 70 F.2d 641 (2d Cir. 1934). HAND had dissented from MANTON's majority opinion. In 1939, the Second Circuit, several months after MANTON's conviction, unanimously reversed the earlier decision and adopted HAND's dissenting opinion. Prof. GUNTHER commented that "[b]y thus limiting his corrupt votes to reasonably close cases and arguably plausible positions, Manton made much of his dishonesty difficult to detect". (GUNTHER, op.cit. at 507)

The Second Circuit continued to enjoy its reputation as the most highly respected US Circuit Court of Appeals with the great triumvirate of LEARNED HAND, as Chief Judge, THOMAS SWAN and AUGUSTUS HAND.

${ }^{3}$ After his resignation from the Second Circuit, and on appeal from his conviction under a federal statute penalizing conspiracy "to defraud the United States", "in any manner or for any purpose", MANTON argued that there had been no defrauding of the US and no obstruction of justice because the cases in which he had received payments from, or on behalf of, litigants, had been correctly decided. Moreover, he had been merely one of the members of the Division sitting on the cases involved and could not by himself have delivered success to the litigants who had paid him. NOONAN, op.cit. supra at 569.

Retired US Supreme Court Justice SUTHERLAND, who had been designated to sit with the Second Circuit to hear MANTON's appeal, was willing to assume that all the cases concerned had been correctly decided. Nevertheless, SUTHERLAND rejected MANTON's argument, holding that correctness of those decisions was not the issue. SUTHERLAND wrote: "Judicial action, whether just or unjust, right or wrong, is not for sale”. United States v. Manton, 107 F.2d 834 at 846 . 
distorts and undermines that norm. Such is the ordinary, garden variety concept of judicial corruption.

The next general submission that might be made is that if corruption in the judiciary is sufficiently widespread, or (what may be functionally equivalent) if the public perception is that such corruption is sufficiently widespread, the other institutions of government - legislative, executive and administrative may be substantially weakened and the government's claim to legitimacy or official rectitude may be substantially eroded. In a community like that we have in my country, erosion and eventual loss of legitimacy must be carefully and self-consciously guarded against. Legitimacy is a finite and exhaustible resource of governments that may be squandered by, among other things, widespread corruption, especially corruption in the judiciary which in the perception of the public, is uncontrolled and unchecked for a prolonged period of time. This is a principal lesson that may be derived from the contemporary still unfolding situation of Venezuela. ${ }^{4}$ Our community relies heavily, almost instinctively, on legal (i.e., statutory) prohibition and criminalization as modes of control of socially undesirable types of behavior. The resulting prescriptions naturally require judicial interpretation and application. Our judiciary is also empowered to intervene decisively in the processes of government by striking down legislative measures as unconstitutional, and executive and administrative acts as unconstitutional or illegal. We have not seriously developed (outside the field of labor relations) alternative, private, non-judicial, methods of dispute resolution - such as mediation and conciliation - and we have barely begun with commercial arbitration. In other words, the judiciary, in our system of government, has a very large and important role to play. By intervening or failing to intervene under certain circumstances, or by the quality of their intervention, the judiciary can in measure affect the course and direction and the pace of social, economic and political development of the country.

Thus we arrive at the nexus between the basic principles and constitutive practices of good governance - with which legal and judicial reform and control of corruption are integral - and national development processes. In the last several decades, there has been increasing recognition that a sound legal

\footnotetext{
${ }^{4}$ The current turmoil and constitutional crisis in Venezuela have been attributed by commentators to the loss of political legitimacy by the traditional political and judicial institutions of Venezuela. It is reported that $94 \%$ of the Venezuelan people distrust the judiciary as corrupt and inept and frequently take the law into their own hands by lynching persons accused of crimes while disputes involving business enterprises remain mired in court for years. The Venezuela legislature is reportedly viewed with the same widespread distrust. In the February 1999 presidential elections, a former unsuccessful coup leader, Mr.HUGO CHAVEZ, was elected President by a landslide vote and a 'constituent assembly' consisting almost completely of Mr.CHAVEZ' party mates, was elected. This 'constituent assembly' has effectively claimed power and authority to 'transform the state' and to dismiss the Venezuelan Supreme Court and to strip the Venezuelan Congress of its legislative functions. The judges of the Supreme Court preferred to resign en masse rather than be physically thrown out of office. See the report entitled "Debunking democracy" by R.COLITT and R.LAPPER, Financial Times, 31 August 1999: 12.
} 
framework or system is a basic prerequisite for the success of the social and economic development efforts of a state..$^{5}$ A sound legal system is not simply a black box which mechanically grinds out legally binding rules. It is most appropriately conceived of as comprising a series of processes by which laws and regulations are formulated and prescribed, applied and enforced, and evaluated and amended or terminated. Good governance relates to the participatory nature, the quality and efficiency and transparency of these processes of lawprescribing, law-applying and law-enforcing, and law-revision or law-repeal. Indispensable for the efficacy of these inter-related processes is the existence of 'well functioning public institutions' staffed by trained individuals who are accountable to the general community and who are bound by and do comply with laws and regulations and apply them in an efficient and transparent manner, without arbitrariness or corruption.

Arguably the most important of those 'well functioning public institutions' is an independent, fair and impartial, honest and well-trained judiciary. In all well-ordered modern societies, the judiciary is not merely the arbiter of disputes between private individuals. It must also resolve citizens' disputes with their own government, their charges of unconstitutional or illegal or arbitrary or corrupt behavior on the part of public officials, as well as conflicting claims of jurisdiction and competence by public agencies inter se.

It should also be noted that the requirements of good governance - which include, again, an independent, impartial, honest and competent judiciary - and the extent to which they are effectively realized within the internal processes of a state, are widely regarded as giving rise to legitimate concerns on the part of other states. Legislation by home countries of multinational corporations have, for instance, defined the giving of bribes to officials of foreign governments as criminal behavior punishable in the home country and the bribes themselves as non-tax deductible.

In 1977, the Foreign Corrupt Practices Act ${ }^{6}$ was enacted by the US Congress and defined as a criminal offence the bribery of foreign officials by US corporations seeking to obtain and do business abroad. The Act did not render criminal all acts of bribery of foreign officials. It explicitly excludes gratuities frequently paid to low-level foreign government officials to secure or expedite the performance of routine non-discretionary duties. These are commonly re-

\footnotetext{
${ }^{5}$ See, in particular, the extensive work done by Dr. I.F.I. SHiHATA, General Counsel of the World Bank on this subject, e.g., SHIHATA, "Good governance and the role of law in economic development", preface to A.SEIDMAN, R.B.SEIDMAN, and T.WÄLDE (eds.), Making development work: legislative reform for institutional transformation and good governance (Kluwer, 1999); SHIHATA, The World Bank in a changing world, vol. II (1995) chap. 3; id., "Complementary reform", in Essays on legal, judicial and other institutional reforms (1997) chap. 1 (Law, development and the role of the World Bank); id., "The role of law in business development", 20 Fordham ILJ (1997) 1577; id., "Corruption - A general review with an emphasis on the role of the World Bank", 15 Dickinson JIL (1997) 451.

${ }^{6} 15$ USC Secs.78m, 78dd-1, 78dd-2, 78 ff. Text in 17 ILM (1978) 214; the Foreign Corrupt Practices Amendments of 23 Aug.1988 appear in 28 ILM (1988) 455.
} 
ferred to as 'facilitating' or 'grease' payments and typically are not made 'for the purpose of obtaining business'. ${ }^{7}$ Payments unlawful under the Foreign Corrupt Practices Act are also denied deductibility under Section 162(a) of the US Internal Revenue Code which authorizes US taxpayers to deduct 'ordinary and necessary' expenses incurred in carrying on a trade or business. ${ }^{8}$

On 29 March 1996, twenty-one out of the thirty-four member states of the Organization of American States (OAS) signed the Inter-American Convention Against Corruption. ${ }^{9}$ In the same year, the United States and Canada, ${ }^{10}$ the principal capital- and technology-exporting countries in the hemisphere, signed this Convention and on 6 March 1997, the OAS Convention went into effect. The Preamble of the OAS Convention eloquently underlines the relationship between democratic legitimacy, development and efforts to combat and control corruption:

"The Member States of the Organization of the American States

Convinced that corruption undermines the legitimacy of public institutions and strikes at society, moral order and justice, as well as at the comprehensive development of peoples;

Considering that representative democracy, as essential condition for stability, peace and development of the region, requires, by its nature, the combating of every form of corruption in the performance of public functions, as well as acts of corruption specifically related to such performance;

Persuaded that fighting corruption strengthens democratic institutions and prevents distortions in the economy, improprieties in public administration and damage to a society' moral fiber;

Recognizing that corruption is often a tool used by organised crime for the accomplishment of its purposes;

$\cdots$

Deeply concerned by steadily increasing links between corruption and the proceeds generated by illicit narcotics trafficking which undermine and threaten legitimate commercial and financial activities, and society, at all levels; [and] ..."

\footnotetext{
7 See L.A.Low, A.K.BJORKLUND and K.C.ATKINSON, "The Inter-American Convention Against Corruption: A comparison with the United States Foreign Corrupt Practices Act", 38 Virg.JIL (1998) 243, 257, 269.

${ }^{8}$ On the deductibility of bribes or 'questionable foreign payments' for tax purposes, see, e.g., M.CHU and D.MAGRAW, "The deductibility of questionable foreign payments", 87 Yale LJ (1978) 1091, and L.DENYS et al., "Bribes as deductible business expenses", 16 European Taxation (1976) 370.

${ }^{9}$ Text in 35 ILM (1996) 724.

${ }^{10}$ Under Act XXIII of the Convention, states which are not members of the OAS may accede to the Convention.
} 
Probably the most important provision of the OAS Convention for present purposes, is Article VIII which sets forth the undertaking of states parties to the Convention to criminalize what is often called 'active bribery' or the giving or offering of bribes, as distinguished from 'passive bribery' understood as the soliciting or accepting of bribes in transnational commerce by foreign government officials. This article reads in part as follows:

"Article VIII. Transnational Bribery

Subject to its Constitution and the fundamental principles of its legal system, each State Party shall prohibit and punish the offering or granting, directly or indirectly, by its nationals, persons having their habitual residence in its territory, and businesses domiciled there, to a government official of another State, of any article of monetary value, or other benefit, such a gift, favour, promise or advantage, in connection with any economic or commercial transaction in exchange for any act or omission in the performance of that official's public functions.

..."

Two observations might usefully be made in this connection. Firstly, the definition of 'transnational bribe' now includes the 'facilitation payments' typically made to minor foreign public officials. ${ }^{11}$ Secondly, the applicability of the Convention's provisions is not dependent upon a showing that the acts of corruption imputed to the accused resulted in harm to state property, that is, that the country of the official bribed has suffered some economic injury by reason of the acts of corruption involved. ${ }^{12}$

Soon after the OAS Convention went into effect, the member states of the Organization for Economic Cooperation and Development (OECD) followed suit and signed a Convention on Combatting Bribery of Foreign Public Officials in International Business Transactions on 17 December 1997. The OECD Convention, like the OAS Convention, recognizes in its preambular paragraphs that the use of bribery by multinational corporations as an instrument in securing and expanding business opportunities, had become common place in some developing countries and that efforts to control and suppress corruption must be supported by international cooperation:

"[B]ribery is a widespread phenomenon in international business transactions, including trade and investment, which raises serious moral and political concerns, undermines good governance and economic development, and distorts international competitive conditions; [and]

\footnotetext{
"Act I, OAS Convention defines 'public official', 'government official' or 'public servant', as meaning "any official or employee of the State or its agencies, including those who have been selected, appointed or elected to perform activities or functions in the name of the state or in the service of the state, at any level of its hierarchy". (Emphasis added)

${ }^{12}$ See Act XII, OAS Convention.
} 
[A]ll countries share a responsibility to combat bribery in international business transactions." 13

The OECD Convention establishes, again much like the OAS Convention, treaty undertakings by states parties to it to enact domestic legislation criminalizing the employment of 'active bribery' by their nationals, individual and corporate, in promoting their business interests abroad. That parties to the OAS Convention or to the OECD Convention may carry out such undertakings not necessarily or exclusively for moral or ethical reasons, but as well for more pragmatic objectives of reducing the comparative cost of doing business abroad and achieving equality of competitive conditions - need not detract from the importance and desirability of implementing those treaty undertakings. ${ }^{14}$

From a national criminal law perspective, the noteworthy effect of statutes like the US Foreign Corrupt Practices Act and of legislation implementing the OAS and the OECD Conventions, is that although some or all of the constituent elements of the act of bribery may occur outside the territorial domain of the state party enacting the legislation, the courts of that state nevertheless acquire jurisdiction to try and punish the corporate officials or representatives offering or dispensing the bribes. Sometimes the realistic prospects of detecting

${ }^{13}$ Text in 37 ILM (1998). It is noteworthy that the bribery of a foreign public official is required, under the Convention, to be penalized as a criminal offence "irrespective of, inter alia, the value of the advantage [secured through bribery], its results, perceptions of local custom, the toleration of such payments by local authorities, or the alleged necessity of the payment in order to obtain or retain business or other improper advantage". See Commentaries on the OECD Convention adopted by the Negotiating Conference on 21 November 1997 para.7, text in 37 ILM (1998) 9. Moreover, bribery of a foreign public official to obtain or retain business or other improper advantage is required to be criminalized "whether or not the company concerned was the best qualified bidder or was otherwise a company which could properly have been awarded the business". Commentaries para.4, ibid. at 8 .

See, further, Convention on the Fight Against Corruption Involving Officials of the European Communities or Officials of Member States of the European Union, recommended by the Council of the European Union on 26 May 1997 for adoption by the Member States in accordance with their respective constitutional requirements, 37 ILM (1998) 12. The EU Convention requires each member state to render both 'passive corruption' and 'active corruption' criminal offences.

REISMAN, op.cit.n.1, at 157 , referring to earlier proposals relating to an international agreement to criminalize bribery by multinational corporations, expresses doubt as to the prospects of success of such an agreement. He notes that the formal code of virtually every country in the world already prohibits bribery. An international agreement might win quick acceptance but result in no more enforcement than is currently obtained under the different domestic laws it replicates.

${ }^{14}$ The OECD has had no monopoly of concern over the use of, or acquiescence in, bribery of foreign public officials by multinational enterprises. The UN Commission on Transnational Corporations produced lengthy studies on a Code of Conduct for Transnational Corporations prohibiting, inter alia, bribery of foreign public officials; so did the UN Economic and Social Council. A useful list of these studies may be found in the extensive bibliography on bribery appended to REISMAN, op.cit.n.1 at 266-267. The 1984 Draft UN Code of Conduct on Transnational Corporations appears in 23 ILM (1984) 602. 
and punishing bribery in transnational business may be greater in the national state or domicile of the multinational enterprise than in the home country of the foreign bribe-taker. Practical immunity in that home country may well form part of the corrupt bargain. There is, too, clear recognition that the bribery of foreign officials affects the interests of the national state or domicile of the bribe-giver.

Finally, it may be observed that the same requirements of good governance are also taken into account, with varying degrees of explicitness, by multilateral financial institutions in the granting (or withholding) and structuring of development loans to developing and transition-economy countries. ${ }^{15}$

\section{THE CONTEXT OF CAUSES AND CONDITIONS}

We turn to the context of more specific causes and conditions within which the problem of corruption among judges may be examined.

By context, one commonly refers to the aggregate of causative and conditioning (that is, environmental) factors within which judicial corruption occurs. It is commonly difficult to distinguish, in the real world, between causes and conditioning factors but, one might believe, it is not really necessary to make such a distinction for preventive and regulatory purposes.

The first of these factors relates to the protracted and complex nature of the judicial process as we know it, which in itself is the result of many factors including the great number of statutes and administrative regulations which have to be judicially applied and controlled. The ultimate outcome is multiplicity of litigations which are processed through the judicial system. The sheer volume of incoming cases is such as to lead to significant congestion of judicial dockets and the slow but inexorable accumulation of backlogs of judges, at least those who are stationed at urban and commercial - industrial centers. ${ }^{16}$

In our country, the congestion of dockets is observable at just about all levels of the judiciary. A sense of the realities of the situation may perhaps be conveyed by citing that in the Supreme Court of the Philippines, in the last ten (10) years (1989-1998), the average number of newly filed cases per year has

\footnotetext{
${ }^{15}$ Sometimes the message is conveyed with considerable explicitness indeed. Consider the following: Recently, on 25 August 1999, the Financial Times, p.12, carried a report entitled "World Bank threatens to stop lending to Indonesia". It had been previously reported that senior officials took bribes to transfer government funds to aprivate bank, Bank Bali, which then transferred more than half the payment (i.e. US $\$ 80$ million) to an agency run by a senior member of the ruling Golkar Party. Opposition leaders accused senior advisers and a younger brother of President B.J.HABIBIE of involvement in the scandal. MARK BAIRD, the World Bank's Indonesia Director, was quoted as stating that "[I]f this case is not resolved early, and satisfactorily, it is difficult for us to provide budget support to the Government of Indonesia". Mr.BAIRD is described by the Financial Times as "now exerting the heaviest foreign pressure on Mr.HABIBIE's government since it took office in May [of 1998]".

${ }^{16}$ See, generally, F.P.FeliCiano and E.L.CAPARAS, "The Problem of delay in the Philippine court system", 62 Philippine Law Journal (1987) 201.
} 
been 5,555.3 cases. The average number of cases disposed of per year during the same period has been $5,282.8$ cases. ${ }^{17}$ While the jurisdiction of the Supreme Court is, in theory,

optional in character, the Constitution requires the Court to explain why it rejects a petition for review or petition for certiorari, which means that each case must be processed and decided one way or the other. ${ }^{18}$ This is true for all courts below the Supreme Court.

It should also be noted that our Judiciary Act, as it stands at present, permits successive appeals - from the Municipal Court to the Regional Trial Court, and then to the Court of Appeals and finally to the Supreme Court. Decisions of administrative agencies may also be tested in the courts, from the Regional Trial Court and onwards.

The net result of the system is that the losing party may try in successive appeals up the hierarchy of courts to reverse the original judgment or, at least delay the finality of the judgment and the execution thereof. This situation creates incentives for attempts by litigants and their lawyers to short-circuit the ordinary lengthy procedure by extra judicial means.

The second element of the context which should be noted is that the levels of compensation in the judiciary are very low, indeed, unreasonably low. A certain disparity in the compensation structures of civil servants and the private sector is, of course, commonplace, especially in developing countries. In the case of the judiciary, however, the disparity is so severe as to be appalling. Not more than $1-1 / 2 \%$ of the national budget is allocated to the judicial department. The figure used to be $1 \%$ until a former Chief Justice lobbied with the Department of the Budget and Management and the legislative department of the government. He quickly found out, however, that there was a limit beyond which

\footnotetext{
17 'Newly filed cases' with the Supreme Court include both judicial cases and administrative (disciplinary) cases involving judges and other officials of the judicial department. The above figures may be grossed up and broken down as follows:
}

I (1) Total judicial cases filed 1 January 1989 to 31 December 1998 -

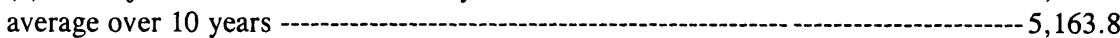

(2) Total administrative cases filed 1 January 1989 to 31 December 1998 -........-.-3,915 average over 10 years $0,391.5$

II (1) Total judicial cases disposed of 1 January 1989 to 31 December 1998-----.----- 49,950 average over 10 years -..-- 4,995

(2) Total administrative cases disposed of 1 January 1989 to 31 December 1998 ----2,878 average over 10 years $0,287.8$

The yearly figures relating to judicial cases were provided by the Judicial Records Office, Supreme Court of the Philippines, courtesy of Atty. Natalie MENDOZA of the Office of the Clerk of Court (en banc), Supreme Court. The year by year figures pertaining to administrative (disciplinary) cases were supplied by the Office of the Court Administrator, Supreme Court; the assistance of Deputy Court Administrator ZENAIDA ELEPAÑO is acknowledged. The figures relating to the dockets of trial courts throughout the country, are much more difficult to assemble. It is believed that the differential between cases disposed of and cases filed, in respect of trial courts, is probably significantly higher than that pertaining to the Supreme Court.

${ }^{18}$ Art. VIII, Sec. 14, 1987 Constitution. 
the independence of the judiciary would be endangered by further lobbying and he decided against further efforts to obtain a higher allocation of budgetary resources.

It is therefore not easy to attract bright young lawyers to the judiciary, except where they have independent means. Of course there are able lawyers who enter the judiciary at a relatively late stage in their professional careers, where substantial savings permit them to treat low judicial compensation levels as secondary in importance. For all, however, acceptance of judicial office requires a strong moral commitment to reject blandishments from, for instance, litigants who go to court to protect an economic interest from either the internal revenue officers or business competitors.

Some perspective is necessary in looking at this factor. Prosperity (in the form of high compensation levels) is not a guarantee of judicial integrity, competence and independence, ${ }^{19}$ any more than poverty (understood as modest pay scales) necessarily means easy judicial virtue or loss of judicial innocence. There is no more inevitability about either judicial corruption or judicial reform than about other important aspects of personal and social life and development. ${ }^{20}$

Another factor to be considered is the public perception of the judiciary in general, to the extent that this perception is reflected in the mass media and opinion polls. There are, of course, in my country as elsewhere, dishonest judges who accept differing kinds of bribes, as well as ignorant judges and those whose personal behavior render them unfit for judicial office. It is not

\footnotetext{
${ }^{19}$ A former senior law officer of a wealthy Asian country made the interesting comment (to the author) that the pay of judges could also be raised to such generous levels as to create marked, if unspoken, inclinations on the part of judges to uphold the position of the government in crucial litigations. It was stated that the pay scale of judges of the highest court in that country very significantly exceeds that of justices of the Supreme Court of the United States. The suggestion, apparently, is that judges, when so generously treated, may be less likely to take an aggressively independent stance vis-à-vis the Legislative and Executive Departments which control the public purse.

${ }^{20}$ Striking illustration is provided in Professor ANDREW KAUFMAN's superb biography of Mr.Justice BENJAMIN N.CARDOZO. Justice CARDOZO is widely regarded as second only to Mr.Justice OLIVER W.HOLMES of the US Supreme Court in the enduring importance and quality of their contributions to the case law of that Court: Cardozo (Harvard Un.Press, 1998). Justice CARDOZO's father, Judge ALBERT CARDOZO who had been elected to and had sat in the New York Supreme Court during the period of Tammany Hall dominance of New York City politics, was forced to resign on charges of corruption, fee-splitting with receivers and Masters of the Rolls appointed by him, etc. Justice CARDOZO almost never spoke of his father, except to say that the affair had taken place a long time ago when he was a young boy and that he remembered ALBERT as a loving father. By the end of Mr.Justice CARDOZO's life, he had redeemed his family honour by the sheer force of the exemplary moral and intellectual qualities of the life he led as a man and as a judge. KAUFMAN, ibid. passim, notes that this extraordinary redemption was accomplished within a single generation. Justice CARDOZO prevented a 'like father, like son' syndrome from arising. In the end, the name 'Judge Cardozo' ceased totally to refer to the disgraced father and recalled instead only to the great and universally respected judge the son had become.
} 
possible to tell whether we have more than our 'fair share' of corrupt judges. ${ }^{21}$ It seems to me, however, that in the last few years, public perception has been generally severe with respect to judges. My personal belief is that there are many, many judges out there who are honest and committed and reasonably competent, but who are voiceless and largely unnoticed in the hurly-burly of episodic media crusades. Two considerations are worth mentioning. One is widespread lack of familiarity among the general public about the structure and requirements of our system for delivering justice. When, for instance, a person accused of crime is acquitted in court, there is an unfortunate tendency on the part of the victim or his family readily to assume either that the judge was ignorant or had been bribed by the accused person.

What is often forgotten is that the courts constitute only the last phase of the justice delivery system and that earlier phases - such as police investigative work, finding and protecting witnesses and other evidence, and preparation and handling of the public prosecutor's case - effectively limit what courts can do by way of reducing criminality. If insufficient admissible evidence is adduced in court - because the police did not do their work or because the public prosecutor was inept - the courts must acquit.

Another consideration is that litigants or their lawyers and even the bar associations have often been reluctant to come out openly against judges they might suspect or who are rumored to be dishonest so that investigation may be commenced. We noted earlier that cultural influences may be at work here. Still another consideration is that there are unfortunately some lawyers who are quick to explain an unfavorable court decision, or a large billing for legal fees, by telling the client that the judge had been 'bought' by the opposing litigant or that a portion of his legal 'fees' had to go to the judge. The client will never know whether or not his lawyer is telling the truth; and the judge, who could be completely innocent, is totally defenseless.

The general point that should be made is that corrupt judges do not exist in a vacuum. There are corrupt judges because, inter alia, there are corrupt lawyers and litigants willing to offer a bribe or who, for diverse reasons, are unwilling to resist a demand for a bribe from an aggressively corrupt judge and who refuse to go to the appropriate judicial authority which can discipline and remove such judges. Judicial reform must begin and go hand in hand with reform of the bar. Clearly, members of the bar and the general public must learn to cooperate with judicial authority, and the latter must in turn convincingly demonstrate its own ability to identify and remove unworthy and unfaithful judges so as to generate and reinforce the habits of trust and cooperation.

\footnotetext{
${ }^{21}$ REISMAN, op. cit.n.1 at 9, acknowledges the methodological problems arising from the fact that although bribery in a particular society might be extant in a greater or lesser degree, "it is conducted in an atmosphere of understandable secrecy". Part of the reason for secrecy, he suggests, arises from fear of sanctions "not for violation of the laws against bribery but rather for violation of the operational code that some types of bribery are acceptable but are not to be talked about", and from the readiness of members of a group to impose effective sanctions on those who deviate from that code.
} 


\section{MODES OF REGULATING AND CONTROLLING JUDICIAL CORRUPTION}

The modes which have been employed in my country to regulate and control corruption among judges, are multiple. There is, firstly, a general effort to upgrade the levels of judicial compensation, on the part of the Executive and Legislative Departments of government. However, there are structural limitations to this strategy, since such upgrading has to take into account the compensation levels of the entire civil service. It simply has not been politically possible to upgrade judicial compensation levels without at the same time upgrading the pay scales of the rest of the government sector. There is constant competition for finite budgetary allocations and the judicial department is at a severe disadvantage in such competition.

More specific strategies relate to the recruitment of judges. In the end, the problem of judicial corruption is the problem of the quality - moral and professional - of members of the bar; for judges are recruited exclusively from the bar. ${ }^{22}$ There are no elective judges in our jurisdiction; there have never been any. Under our earlier (i.e., the 1935 and 1973) Constitutions, the appointment of all judges was vested in the President of the Republic, but such appointment was subject to confirmation by the Commission on Appointments - consisting of Members of the Senate and the House of Representatives. To minimize the perceived influence of political factors on the selection of judges, our present (1987) Constitution has done away with the need for confirmation by the Commission on Appointments. Instead, nominations to judicial posts are made by a Judicial and Bar Council composed of seven members: the Chief Justice of the Philippines, the Secretary of Justice and a Member of Congress as exofficio Members; and a representative of the Integrated Bar, a law professor, a retired Member of the Supreme Court and a representative of the private sector. ${ }^{23}$ The Chief Justice is ex-officio Chairman of the Council. Three or more nominations are made for each judicial vacancy; the final choice and the appointment is made by the President of the Republic. ${ }^{24}$ This procedure makes possible a more focused effort to scrutinize carefully the record and credentials (personal and professional) of would-be judges. The list of names under consideration for nomination is published in national newspapers and bar associations and the public are invited to comment on those names. The Judicial and Bar Council may also interview the candidates for nomination. The process is generally analogous to the process of recruitment for positions in private corporations and enterprises.

The next effort to upgrade the quality of judges comes promptly upon the appointment of new judges. They are required to undergo training courses at the Philippine Judicial Academy, an entity originally created by an Administra-

\footnotetext{
${ }^{22}$ Art. VIII, Sec. 7(2), 1987 Constitution.

${ }^{23}$ Art. VIII, Sec. 8(1), 1987 Constitution.

${ }^{24}$ Art. VIII, Sec. 9. 1987 Constitution.
} 
tive Order of the Supreme Court and later reconstituted and chartered by statute and maintained by Government. ${ }^{25}$ In addition, special courses and seminars are offered at the Academy; those hopeful of promotion to higher courts must confront the task of taking and passing these courses.

A third mode of control of judicial corruption relates to the administrative supervision exercised by the Supreme Court, by constitutional mandate, ${ }^{26}$ over all courts and court personnel. Perhaps the most important aspect of this supervision is the monitoring of the administrative performance of judges, i.e., the state of their judicial dockets and the disposition of cases within the prescribed period of time. This monitoring makes possible the rationalization of the distribution of case loads; additional judges are moved to districts generating high numbers of cases.

The supervisory jurisdiction of the Supreme Court over lower courts is not limited to administrative matters. ${ }^{27}$ The Supreme Court has disciplinary jurisdiction over all judges of lower courts. ${ }^{28}$ It receives and investigates complaints against judges. When probable cause is shown, formal charges are filed against a judge by the Court Administrator and hearings where the respondent judge is given the opportunity to defend himself, are held by a Regional Trial Court judge or by a Member of the Court of Appeals designated by the Supreme Court. The designated judge renders a report which is reviewed in a formal proceeding by the Supreme Court. In this proceeding, the respondent is accorded the opportunity to rebut the findings and recommendation of the investigating judge or justice. Thereafter, the Supreme Court renders judgment either dismissing the charges or penalizing the respondent judge. The penalties range from reprimand to dismissal. ${ }^{29}$ Where appropriate, the Court may also order

\footnotetext{
${ }^{25}$ See, in this connection, A.A.MELENCIO-HERRERA, "Legal and judicial education reforms and the Narvasa Court" in Odyssey and Legacy: The Chief Justice Andres R. Narvasa Centennial Lecture Series (1998) 40 et seq.

${ }^{26}$ See Article VIII, Section 6 of the 1987 Constitution.

${ }^{27}$ In Maceda v. Vazquez, G.R. No. 102781, April 22, 1993, 221 SCRA 464, the Supreme Court declared that this administrative supervisory and disciplinary authority over all lower courts is vested exclusively in the Supreme Court, and not shared by, e.g., the Office of the Ombudsman.

${ }^{28}$ Art. VIII, Sec. 11, 1987 Constitution.

${ }^{29}$ The following data were provided by the Office of the Court Administrator, an agency directly under the supervision of the Supreme Court of the Philippines; the assistance of Deputy Court Administrator ZENAIDA ELEPAÑO is once again acknowledged with appreciation:

As of 31 March 1999, the total number of lower court (i.e., trial) judges in the Philippine judiciary was 1524. On the same date, the number of vacant positions of trial judges was 694 .

During the period from 1989 to 1999, a total of 43 lower court judges were dismissed from office by the Supreme Court: 14 were Regional Trial Judges; 28 were Metropolitan or Municipal Trial or Circuit Trial Judges and 1 Shariá Circuit Court Judge. Of these, eight were dismissed on charges of violation of the Anti-Graft and Corrupt Practices Act; twelve on charges of gross misconduct; seven on charges of grave abuse of authority; five on charges of immorality and disgraceful conduct; five on charges of inefficiency and failure to decide a case within the reglementary period; two on charges of ignorance of the law; one for violation of the Code
} 
the initiation of criminal proceedings against the offending judge. Formal proceedings against respondent judges of course take time. But once they are ripe for decision, the Court assigns high priority to the resolution of such disciplinary proceedings.

A fourth mode of control - a fairly obvious one - is legislation that would limit the availability of successive appeals and provide for finality of judgments of the Court of Appeals in many types of cases, except those which, by constitutional provision, pertain to the exclusive jurisdiction of the Supreme Court. During the decade of the 90s, at least two bills were filed in our Congress seeking to do just that with respect to decisions of certain administrative, quasijudicial agencies, such as the National Labor Relations Commission, whose decisions may be reviewed by the Court of Appeals on certiorari. The bills failed of enactment.

Another measure adopted by the Supreme Court, in the exercise of its administrative supervision, relates to the introduction of new electronic methods of court reporting. The objective here has been the reduction of the period of delay in the conduct of trials occasioned by the need for manual transcription of court stenographers' notes. The new methods make possible the completion of the transcript of oral hearings almost immediately after the end of each hearing. The acquisition of this new technology requires very significant capital investment, as does the re-training of present stenographers. It remains to be seen what degree of success in shortening litigation can be achieved with these new methods.

The degree of success of any particular strategy of prevention and control is commonly difficult to determine. What is perhaps most important, in the end, is that all available strategies must be employed with sustained commitment, fairness and large quantities of common sense. A sense of the human condition and an understanding of social powers would also be valuable in this enterprise.

A final reflection. This relates to the role of personal leadership in the task of judicial reform. Necessarily, in our system, the main burden of this leadership falls on the Chief Justice of the Supreme Court of the Philippines. Certain

of Judicial Conduct; one for knowingly rendering an unjust decision; and two for habitual absenteeism and falsification of certificates of service (i.e., disposition of pending cases).

From 1995 to 1999, a total of 12 lower court judges were penalized with suspension.from office without pay for varying periods of time, for offences ranging from violation of the AntiGraft and Corrupt Practices Act, through gross ignorance of the law, sexual harassment and delay in rendering decisions.

From 1987 to 1999, 137 lower court judges were penalized with monetary fines in amounts equivalent to from 10 days salary to 2 months salary, for offences ranging from gross ignorance of the law (the most common offense) through serious misconduct in office and grave abuse of authority to immorality and knowingly rendering an unjust judgment.

Finally, from 1990 to 1999, 57 lower court judges were 'reprimanded' for a variety of minor offences while from 1987 to 1999, 75 lower court judges were 'admonished' for much the same kinds of offences. 
qualities of heart, mind and will are indispensable for the successful assumption and discharge of the burdens and responsibilities entailed by that leadership. This burden, however, must realistically be shared by the Presiding Justice of the Court of Appeals and the Executive Judges of the Regional Trial Courts and of the Municipal Trial Courts. With such leadership, and with an informed and supportive citizenry, and a strong and vigilant bar itself deeply committed to professional reform, much may be expected by way of progress in judicial reform. 